\title{
THE ROLE OF ENGLISH PROVERBS IN THE DEVELOPMENT OF WRITING SKILL ${ }^{1}$
}

\section{Sudiran ${ }^{2}$}

Abstract: Writing ability plays an important role in the students' academic life. Students' activities cannot be separated from writing. They have to write projects, propose a research, write a research report, etc. Writing ability enables students to disseminate information and new findings. This study aims (1) to describe the use of English proverbs to enhance the students writing achievement, (2) to reveal students' competence to write a purposive paragraph. (3) to describe the students' response to the use of the English proverbs in writing skill. The result of the study shows that (I) English proverbs can be considered as statement containing moral values. English proverbs can be used as teaching aids in teaching writing. (2) English proverbs enable lecturers to promote students' writing ability. This fact can be supported by the result of students' writing test that is 74.62 , which can be categorized into a good category, such as proposed by Hartfiel et. al's Learning ESL Composition. (3) Based on the students' response, generally they have positive attitudes toward the use of English proverbs because it can help them to increase their writing ability. Moreover, English proverbs enable students to elaborate their ideas in writing a paragraph.

Key words: English proverbs, development, writing skill

\section{INTRODUCTION}

Writing can be regarded as one of educated people's activities. Writing enables people to disseminate information and new findings. In

1 This paper is a summary of research conducted at a private university in Malang, East Java.

2 nre Sudiran, M.Hum. <sudiran@yahoo.com> is a lecturer at Muhammadiniversity of Malang in East Java. 
academic life, writing ability plays an important role in the students' success to achieve their goals. Many teachers give assignment to measure the student's mastery of the lesson. In some occasions, teachers assign their students to manage an excursion to some tourism objects. Then, they have to write an excursion report to describe what they have observed. Writing ability also enables teachers to go over the students' progress with their subjects when they do the last learning evaluation in which they have an essay exam requiring them to write a good essay based on the topics given.

In a global society, writing ability is very important for everyone to enhance his career because most professions need writing skill. A manager of a research and development of a company, for example, needs writing ability to propose a new project proposal. A secretary, moreover, has to master writing skill because her dominant activities in her office are to write reports. Besides, there is a profession that requires both oral and writing ability simultaneously that is teachers. Not only does a qualified teacher speak before his class but also write an applicable teaching plan in order that $s /$ he achieves her/his instructional goals. Inman and Gardner (1979:4-5) state that in physical science, the use of language as a tool is just as important as the use of mathematics. A lack of facilities to express our thought inhibits creativity as much as a lack of ability to handle numbers. Graduate schools and professional schools look for a higher degree of literacy when they select students.

It is undeniable that a good essay starts with an intelligible paragraph. If someone reads an essay or an article of a newspaper or a magazine, he/she will realize that he/she has to read paragraph by paragraph to catch the idea from the printed words. He/she does so because a writer writes what he/she feels, thinks, and experiences in a paragraph system. In other words, if a writer expects that his/she writing can be understood easily by many readers, $\mathrm{s}$ /he should write a purposive paragraph because a paragraph is a basic unit of an essay led by a topic sentence.

A paragraph is purposeful when it conveys writers' ideas to readers. Consequently, a writer is expected to pay attention to the parts of a paragraph which includes a topic sentence, one or more supporting sentences, and a concluding sentence. Walker (1983:162) remarks that a paragraph may begin with a topic sentence which states the main idea. It 
tells the reader what the paragraph is about.

This study analyzes the role of English proverbs in the students writing achievement. It tries to describe the competence of the students to use proverbs in writing a paragraph. As teaching aids, English proverbs are expected to improve the students' writing skill. Therefore, this study is based upon the problem of how the use of English proverbs is able to help students improve their writing achievement.

In accordance with the statement of the problem above, this study aims:

1. to give complete description of the use of English proverbs to enhance the students' writing achievement. In this case, the researcher analyzes the aspects of writing ability namely, content, organization, vocabulary, language use, and mechanics. (read "The use of English proverbs to develop the students' writing ability").

2. to reveal students' competence to write a purposive topic sentence because it is very important for students to elaborate ideas. A topic sentence can be regarded as a key point in developing writing ability. It determines the rest of the supporting sentences upon which the development of a topic sentence is based (read 'Students' writing ability").

3. to describe the students' response to the use of the English proverbs in writing skill. In this study, the proverbs as wise expressions of philosophers can be categorized into vocabulary aspect that enables students to develop writing ability.

English proverbs can be categorized into wise sayings to express advices for other people, and lecturers can use them as teaching aids to motivate students in order that they can increase their writing achievement. Proverbs usually consist of good vocabulary that enables students to build their vocabulary as a primary aspect of writing ability. Gnoinska (1989:12) remarks that many students consider learning vocabulary a tedious job. They try to study list words: spelling, pronunciation, meaning, synonymous, only to realize a few hours later that their results are hardly satisfactory. They start blaming their poor memory. They say they are discouraged by the number of words in English and the complex usage. 
Teachers, however, keep looking for ways to substitute rote repetition with more effective techniques and to make learning vocabulary easier and more pleasant. They develop various mnemonic strategies employing action, music, drawing, and fantasy. With this idea in mind, the writer set out to conduct classroom research, looking for practical ways to make classes livelier and help the students acquire English vocabulary, in turn, they can increase their writing ability.

Besides, Samekto (1994:5) said that proverbs come from various sources, such as religious teaching, fairy tales, fables, and ancient stories. A proverb is a statement containing a message or moral which can be used to explain a situation or make it more significant. A proverb can also enable students to compare the typical cultural differences between English speaking cultures and other language or culture which are described through proverbs. There are some examples of English proverbs:

1. Actions speak louder than words. It means that a person's actions are more important than what he/she says.

2. By learning to obey, we know how to command. It means that a person should first learn to obey in order to be able to command.

3. Custom makes all things easy. It means that the more times one does something, the easier it gets.

It seems that writing can be considered as difficult task for many students. They got frustration when their teacher asked them to write a purposive paragraph. They thought they could do nothing with a pen and the paper. They knew nothing how to write an intelligible paragraph. This fact is supported by the research of Alwasilah (2001:2) conducted in West Java. He concluded that:

1. Writing has been the most neglected subject in high schools.

2. Writing is the most difficult language skill to acquire by students and to teach by teachers.

3. High school students as well as college students have been subjected to inexperienced teachers or professors.

4. Writing classes are dominated by discussions on grammar and theories of writing with less exposure to the practice of writing. 
5. In most cases, students' writings are not corrected or returned to the students.

6. The most effective and the only way of teaching writing is through the practice of writing.

Based on Alwasilah's ideas above, it seems that the students need writing practice to improve their writing ability. Moreover, teachers need to develop a new teaching strategy or a technique with which they can enhance students writing achievement. As mentioned before, writing skill is very important for students to master because it determines their success to achieve their goal. It plays a decisive role in the students' career when they finished their study. As a result, teachers are expected to create a new method that enables them to develop the students writing ability.

Writing is an academic job that enables students to improve their ability in proposing a research proposal and disseminate new findings. According to Davis (1998:25), learning how to write in English is essential to many language learners, particularly those who are studying at colleges or universities. Writing is essentially a creative process and good writers must leam to communicate their ideas clearly to an unseen audience. This takes a lot of practice. However, foreign language learners have traditionally learned to write by completing fill-in-the-blanks exercises which focus on accuracy rather than on the composing process. Creative writing, on the other hand, gives leamers practice in composing and complements more traditional approach. Although the ability to produce error-free writing is desirable, this study describes activities that focus on communication and self-expression. The students will be encouraged to write if writing tasks motivate them and keep them interested.

Moreover, according to Harris (1993:10), it is common truth that much of our learning, in the most general sense, is acquired through language and that our perceptions of experience are, in turn, influenced by the inherent cultural bias of our mother tongue. Students, in fact, actively construct their view of the world- including value systems, beliefs and attitudes through language.

Troyka (1987:2-3) suggests that writing gives students unique opportunities to explore ideas and acquire information. By writing, students come to know the subject well and make them their own. Even thirty years 
Grogines si! pue armos

:I गIQEI.

\begin{tabular}{|c|c|c|}
\hline $100 \mathrm{~d}$ & $e s-\cos$ & $\bullet$ \\
\hline จีะบคมท & IS ${ }^{-}$LL & $\varepsilon$ \\
\hline poop & $2 z-68$ & $z$ \\
\hline 1UDIPOXg & क6- TOI & a \\
\hline C1020180 & saveos & ON \\
\hline
\end{tabular}

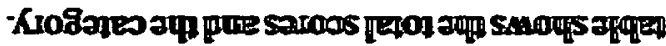

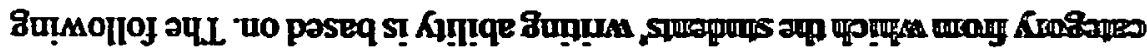

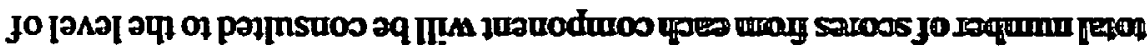

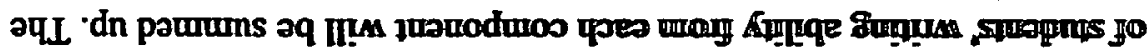

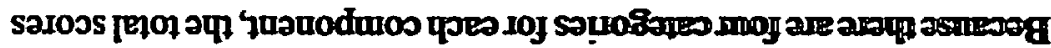

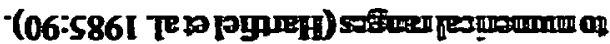

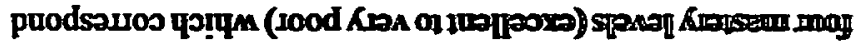

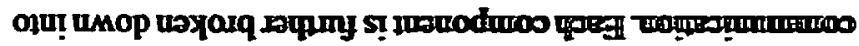

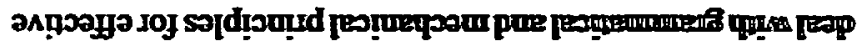

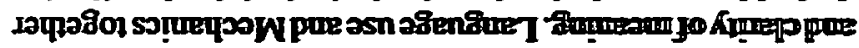

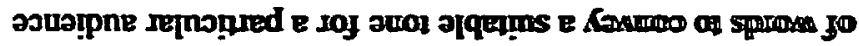

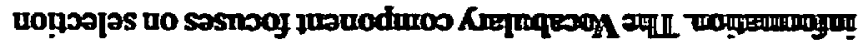

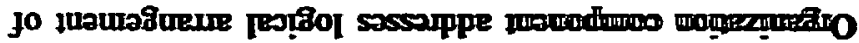

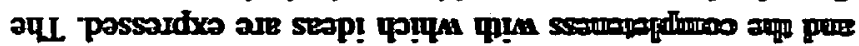

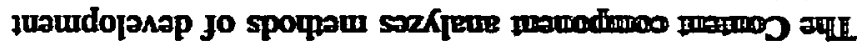

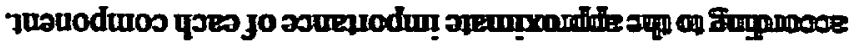

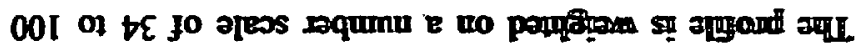

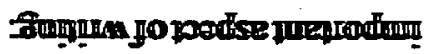

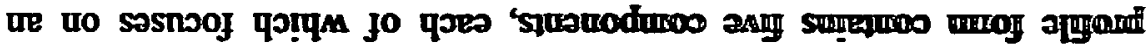

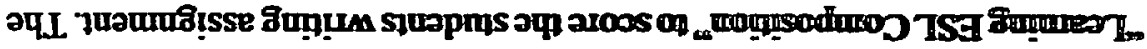

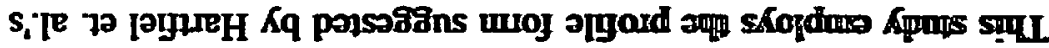

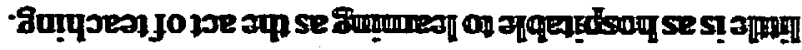

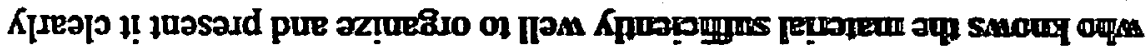

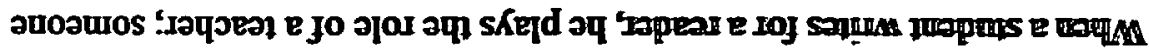

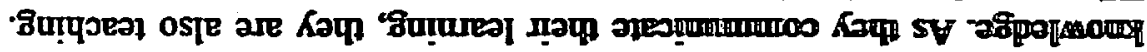

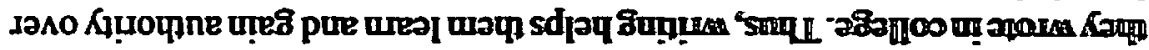

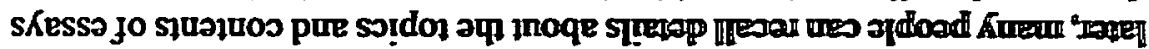


Sudiran, The Role of English Proverts in the Developtanent of Whining Staill 135

\section{RESEARCH DESIGN}

This study used descriptive method became the datia mere callected by writing test and questionnaires. Writing or essay tests were used to kmow the students' mastery on writing achievement after they were tanght with English proverbs. Questionnaires were used ton kmow sturdeants respomse to the use of English proverbs. Further, this stuedy was comdireted at Englisim

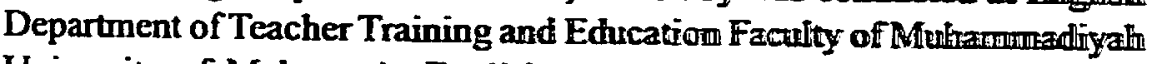
University of Malang. At English Departmemt, there were 5 classes of writing I course, each of which was dividedi into two grounp, $A$ amdi $B$ consisting of 21 students each. This study took one of the tem groups as the sample of the research.

\section{A. Writing test}

The test was designed to obtain the data of stundents" writing aloilityThe population of this study was one class comtaning 21 students attended writing course I. The test aims to know the stiendents' writing albility, and it covered five components namely, contents, organizatiom, vocalbulaury, language use, and mechanics. After the datr were collected, the researcher analyzed them into Hartfiel' ESL Composition Profile and classififed then into the category such as excellent to very goerd, good to average, fair to poor, and very poor.

\section{B. Questionnaires}

After giving the test, the researcher distuthuted questionmaires which consisted of 5 questions to the students. The questionmaires anm to kmow the students' responses to the use of English pnoverbs in teaching minimg process. The questionnaires covered questions such as "Do you like reading English proverbs? Do English proverbs give you advantages? Do English proverbs inspire you to write something? Do you start your essay with English proverbs you like? And do you think that witing an essay started by an English proverb is meaningful?" 


\section{RESULTS}

A. The use of English proverbs to develop the students' writing ability

English proverbs are statement or message that gives moral value to other people. As message containing moral value, they can be used as teaching aids because they can motivate the students in order to learn writing seriously. Motivating the students in a classroom is one of the functions of teaching aids. Therefore, English proverbs are expected to motivate students in order to master writing course that they learn.

When this study was conducted, the teacher used the English proverbs as teaching aids, which have the following functions:

1. to stimulate the students in a classroom to master the subject matter that is writing I course.

2. to give the same experiences to the students to avoid misunderstanding when they learn the subject taught by the teacher.

3. to create the same perception to the students about the material taught by the teacher.

The procedures of giving the English proverbs to the students are as follows:

1. The teacher selected some English proverbs at his teaching plan.

2. He showed the English proverbs selected to the students by using LCD.

3. He asked the students to guess the meaning of the English proverbs.

4. He asked the students to discuss the application of the English proverbs.

5. Then, the teacher asked the students to write a paragraph about their personal experience that started with suitable English proverbs.

\section{B. Students' writing ability}

As mentioned before, this study took 21 students as the sample from 10 groups or 5 classes. The group of students used as the sample was taken 
by using random sampling techniques. To know their writing ability, the researcher computed the total score of each component and categorized it into one of the classifications. The total scores of the students writing ability test were 1567 while the total students were 21 . As a result, the ability of the students in writing was the total scores divided by $21(1567 / 21)$ that is 74.62 . It means that the ability of the students in writing was 74.62 . Then, this point was consulted to the table of writing-mastery category proposed by Hartfiel et. al. (1980: 90), and it was located between 72 and 89 . It belongs to "Good" category. Thus, the ability of the students in writing a paragraph was good (see appendix 1).

\section{Students' response to the use of English proverbs}

The students' response to the use of English proverbs can be seen in the students' answers for the questionnaire below:

1. Doyoulike English proverbs?

There are 15 students who answered yes while the rest of 6 students answered no. It means that $71.43 \%$ of students like English proverbs, and $28.57 \%$ of students dislike English proverbs.

2. Do English proverbs give you advantages?

The students who answered yes to this questions total 13 while the rest of students total 8 answered no. It can be said that $61.90 \%$ of students like English proverbs, and $38.10 \%$ of students dislike English proverbs.

3. Do English proverbs inspire you to write something?

There are 14 students who answered yes while the rest of 7 students answered no. It means that $66.70 \%$ of students like English proverbs, and $33.30 \%$ of students dislike English proverbs.

4. Doyou start your essay with English proverbs you like?

There are 17 students who answered yes while the rest of 4 students answered no. It means that $80.95 \%$ of students like English proverbs, and $19.05 \%$ of students dislike English proverbs. 
5. Do you think that writing an essay started by an English proverb is meaningful?

There are 12 students who answered yes while the rest of 9 students answered no. It means that $57.14 \%$ of students like English proverbs, and $42.86 \%$ of students dislike English proverbs.

Based on the students' response of the questionnaires above, it can be concluded that generally the students have positive attitudes toward the use of English proverbs because it can help them to increase their writing ability. Moreover, English proverbs enable students to elaborate their ideas in writing a paragraph.

\section{CONCLUSION}

It can be concluded that the teacher applies several steps to use English proverbs in a classroom such as, preparing some English proverbs at his teaching plan, showing the English proverbs selected to the students by using LCD, having students guess the meaning of the English proverbs, having students discuss the application of the English proverbs, having the students to write a paragraph about their personal experience started with suitable English proverbs.

Next, the students' ability in writing a paragraph can be categorized into good. This category is supported by the result of the data analysis. whose total score is 1567 . Those scores were divided by 21 , and gave the result 74.62 , which according to Hartfiel et. al.'s criteria belong to a good category.

Lastly, the response of the students to the use of English proverbs is positive. Most students think they can write a good paragraph with an English proverb as a topic sentence. They like English proverbs very much because the English proverbs contain moral values that motivate them to be successful leamers. 
Sudiran, The Role of English Proverbs in the Development of Writing Skill 139

\section{BIBLIOGRAPHY}

Alwasilah, A Chaedar. "Empowering College Students Writers Through Collaboration". In TEFLIN Journal Vol. XII. No. 1 February 2001:2-4.

Davis, Stephen J. "Creative Writing”. In English Teaching Forum. Vol. 36 No. 4 October.- December, 1998.

Gnoinska, Anna. "Teaching Vocabulary in Color". In English Teaching Forum. Vol. 36 No. 3 July September 1989: 12-13.

Harris, John. “Introduction Writing”. New York: Penguin Books Ltd, 1993.

Hartfiel, V. Faye et al. Learning ESL Composition. Rowley, Massachusetts: Newbury House Publisher Inc. 1985.

Inman, Billie Andrew and Gardner Ruth "Aspect of Composition $2^{\text {mt }}$ Ed". New York: Harcourt Brace Jovanovich, 1979.

Samekto, Cecilia G. Popular Proverbs. Yogyakarta: Kanisius, 1994.

Troyka, Lyn Quitman. Handbook for the Writers. New Jersey: Prentice-Hall Inc., 1987.

Walker, Bonnie L. Basic English Composition. Maryland Media material Inc., 1983. 
140 Celt, Volume 7, Number 2, December 2007: 129 - 141

\section{Appendix 1:}

The students' scores of writing ability

\begin{tabular}{|c|c|c|c|c|c|c|c|}
\hline No & Content & Organiz & Voċab & Language use & Mechanics & Ttl & Calegory \\
\hline 1 & 26 & 17 & 14 & 17 & 3 & 77 & Good \\
\hline 2 & 26 & 14 & 14 & 15 & 4 & 73 & Good \\
\hline 3 & 17 & 13 & 13 & 11 & 3 & 57 & Averg \\
\hline 4 & 26 & 17 & 17 & 17 & 3 & 80 & Good \\
\hline 5 & 26 & 17 & 17 & 17 & 3 & 80 & Good \\
\hline 6 & 26 & 17 & 15 & 17 & 4 & 79 & Good \\
\hline 7 & 28 & 17 & 14 & 18 & 3 & 80 & Good \\
\hline 8 & 19 & 13 & 17 & 17 & 4 & 70 & Avrg \\
\hline 9 & 28 & 18 & 17 & 18 & 4 & 85 & Good \\
\hline 10 & 26 & 18 & 17 & 18 & 3 & 82 & Good \\
\hline 11 & 22 & 15 & 15 & 18 & 4 & 74 & Good \\
\hline 12 & 25 & 15 & 14 & 18 & 4 & 76 & Good \\
\hline 13 & 20 & 15 & 17 & 17 & 4 & 73 & Good \\
\hline 14 & 26 & 18 & 17 & 15 & 4 & 80 & Good \\
\hline 15 & 22 & 14 & 14 & 18 & 4 & 72 & Good \\
\hline 16 & 24 & 18 & 17 & 10 & 3 & 72 & Good \\
\hline 17 & 22 & 16 & 17 & 12 & 4 & 71 & Averg \\
\hline 18 & 20 & 17 & 16 & 14 & 4 & 71 & Averg \\
\hline 19 & 22 & 18 & 14 & 18 & 3 & 75 & Good \\
\hline 20 & 20 & 14 & 15 & 17 & 4 & 70 & Averg \\
\hline 21 & 18 & 15 & 16 & 17 & 4 & 70 & Averg \\
\hline & & & & & & 1567 & \\
\hline & & & & & & 74.62 & Good \\
\hline
\end{tabular}

\section{Appendix 2:}

Questionnaire for students

This questionnaire aims to find out your response to the use of English proverbs in writing subject. Your answers will be used for research purposes 
Sudiran, The Role of English Proverbs in the Development of Writing Skill 141

only. Please give check $[\sqrt{ }]$ marks on the box below the questions according to your opinion.

1. Do you like English proverbs?

aYes aNo

2. Do English proverbs give you advantages?

aYes aNo

3. Do English proverbs inspire you to write something?

aYes aNo

4. Do you start your essay with English proverbs you like?

aYes aNo

5. Do you thing that writing an essay started by an English proverb is meaningful?

aYes $\quad$ No 